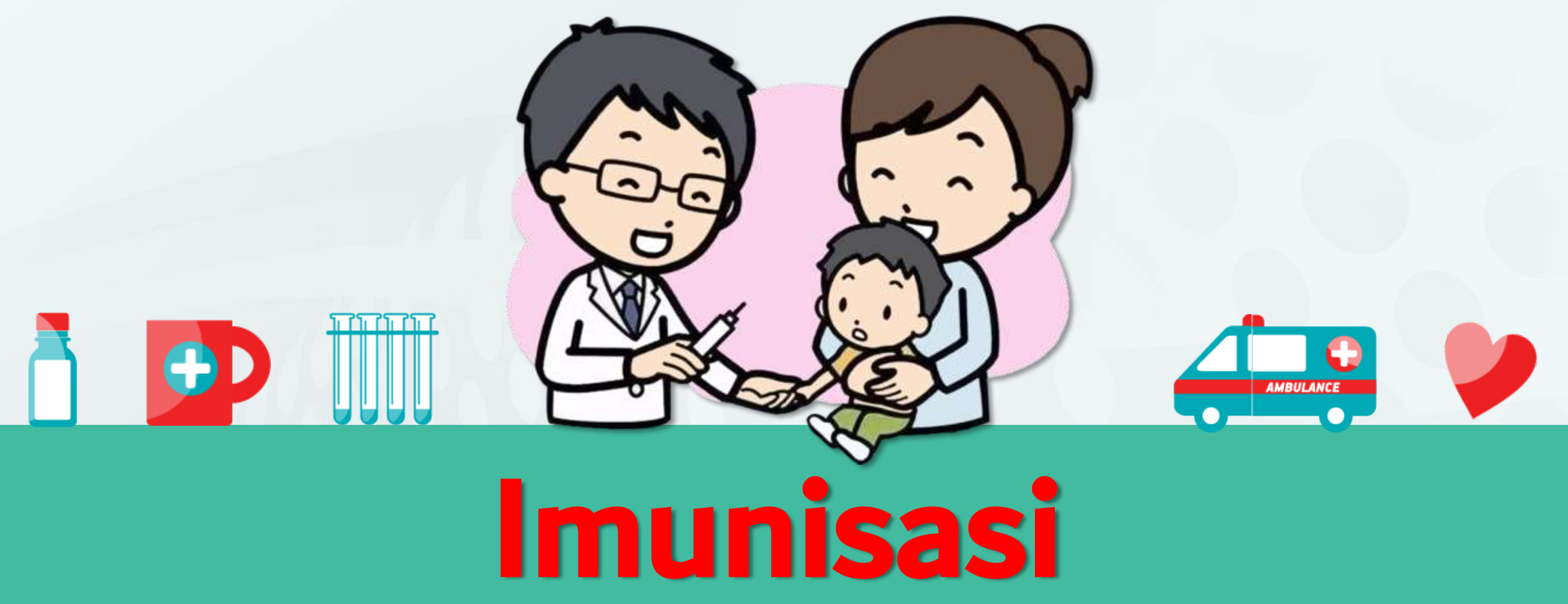

Rindi Dwi Cantika

$J^{\prime}$

70200120001 


\section{Apa itu Imunisasi ?}
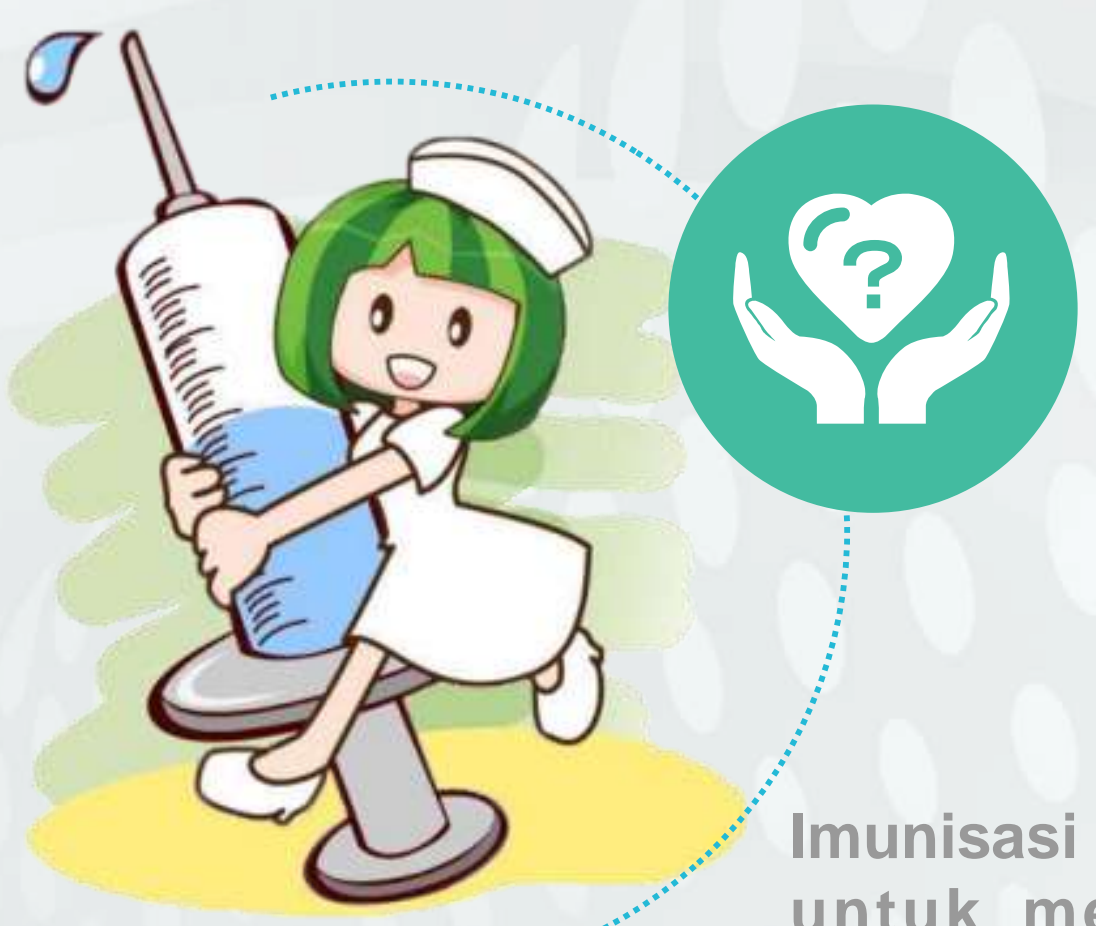

Imunisasi adalah proses memasukkan antibodi ke dalam tubuh agar didapatkan kekebalan yang tidak terbentuk sendiri oleh tubuh kita tetapi di peroleh dari luar tubuh

Imunisasi juga dapat diartikan sebagai cara untuk meningkatkan kekebalan tubuh seseorang terhadap suatu penyakit, sehingga bila kelak terpajan pada penyakit tersebut ia tidak akan menjadi sakit.

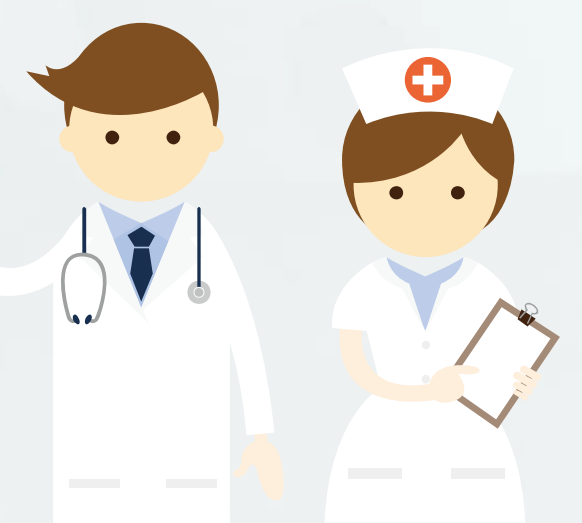




\section{Dasar Hukum Imunisasi}

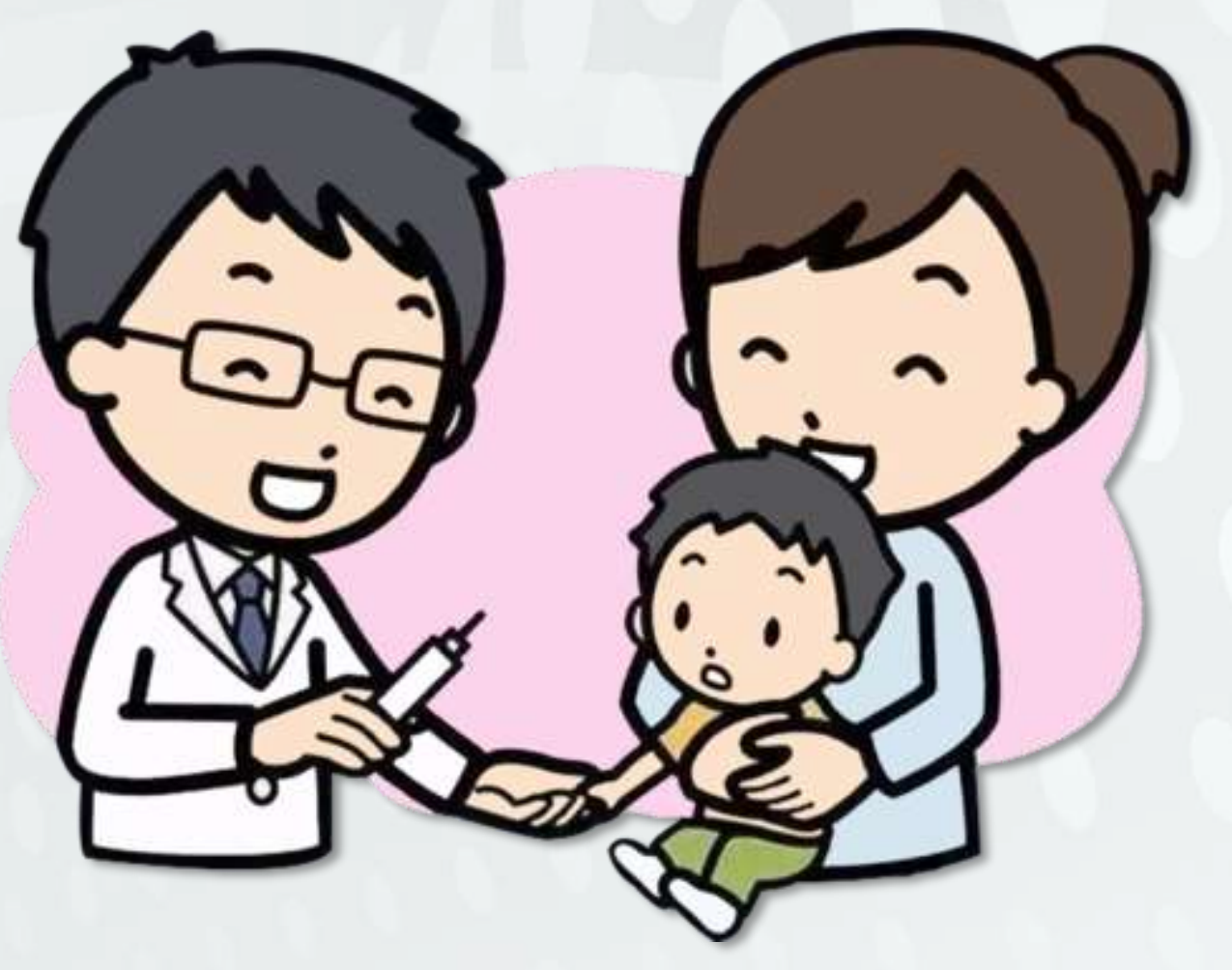

Pasal 132 ayat (4), UUD no 36 tahun 2009

"Setiap anak berhak memperoleh imunisasi dasar sesuai dengan kententuan yang berlaku untuk mencegah terjadinya penyakit yang dapat di hindari melalui imunisasi" 


\section{Tujuan dan Manfaat Imunisasi}

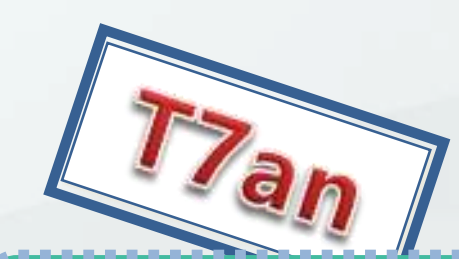

\section{Direktorat Promkes}

agar memdapatkan imunitas atau kekebalan anak secara individu dan eradikasi atau pembasmian sesuatu penyakit dari penduduk sesuatu daerah atau negeri. Sedikitnya $70 \%$ dari penduduk suatu daerah atau negeri harus mendapatkan imunisasi. Yang tidak kalah pentingnya adalah imunisasi ulang (booster) yang perlu dilaksanakan dalam waktu-waktu tertentu untuk meningkatkan kembali imunitas/kekebalan penduduk

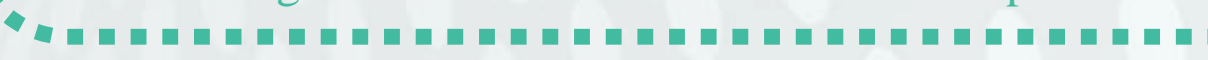

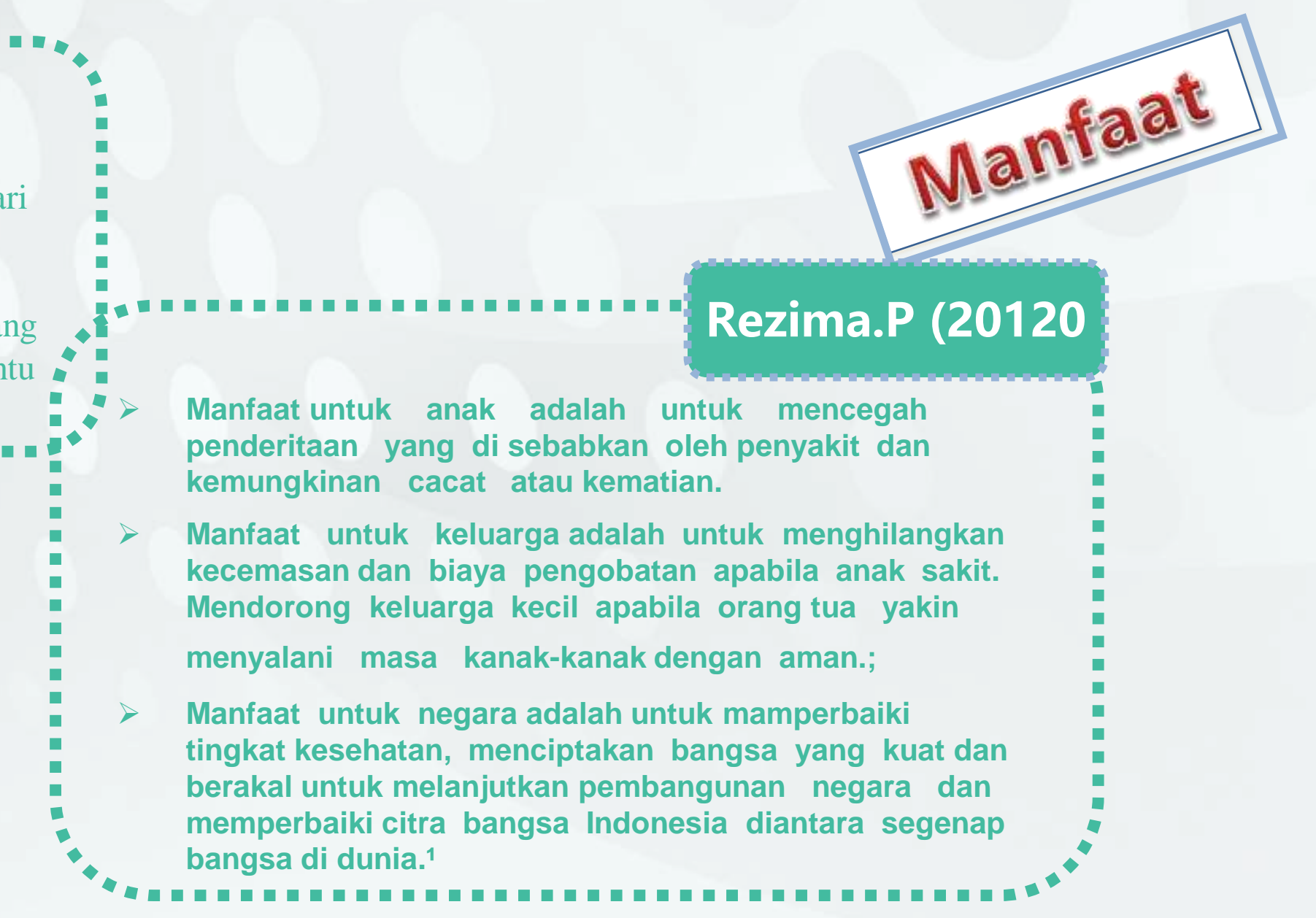




\section{Pembagian Imunisasi}

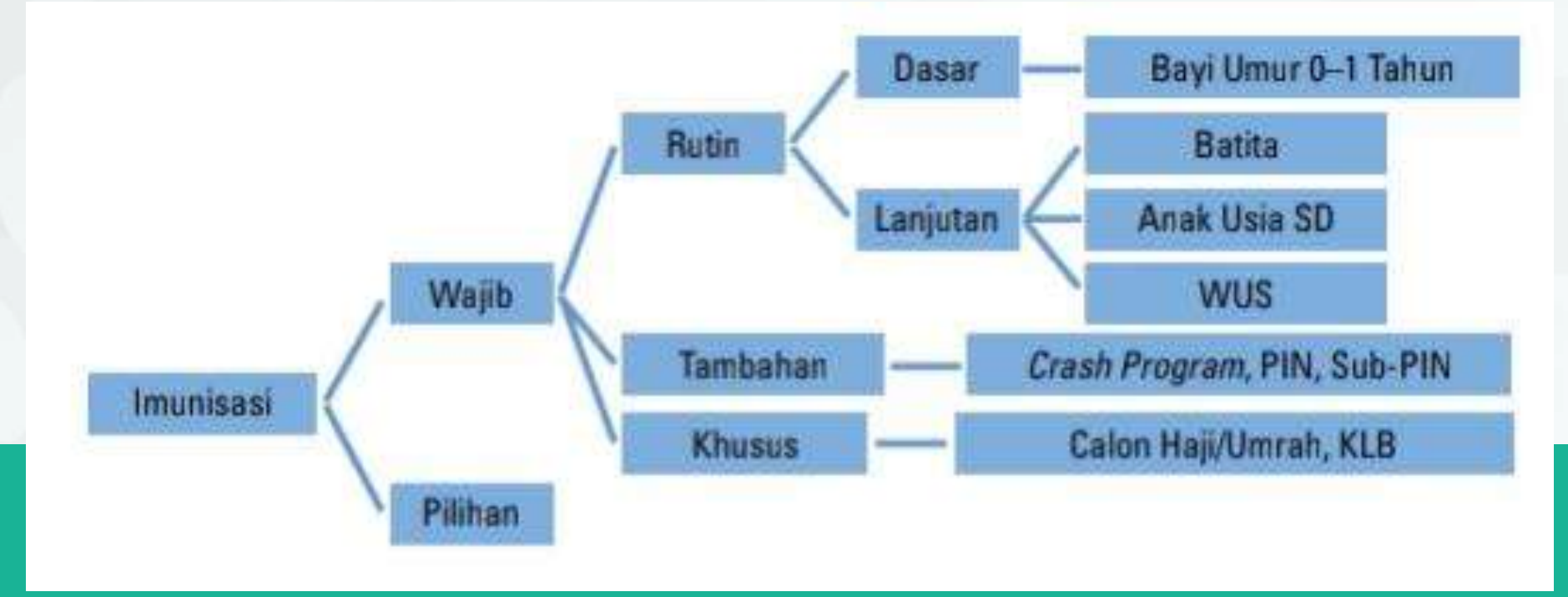

\section{Penjelasan :}

- Imunisasi wajib merupakan imunisasi yang diwajibkan oleh pemerintah untuk seseorang sesuai dengan kebutuhannya dalam rangka melindungi yang bersangkutan dan masyarakat sekitarnya dari penyakit menular tertentu. Imunisasi wajib terdiri atas imunisasi rutin, imunisasi tambahan, dan imunisasi khusus.

- Imunisasi pilihan merupakan imunisasi yang dapat diberikan kepada seseorang sesuai dengan kebutuhannya dalam rangka melindungi yang bersangkutan dari penyakit menular tertentu, yaitu vaksin MMR, Hib, Tifoid, Varisela, Hepatitis A, Influenza, Pneumokokus, Rotavirus, Japanese Ensephalitis, dan HPV. 


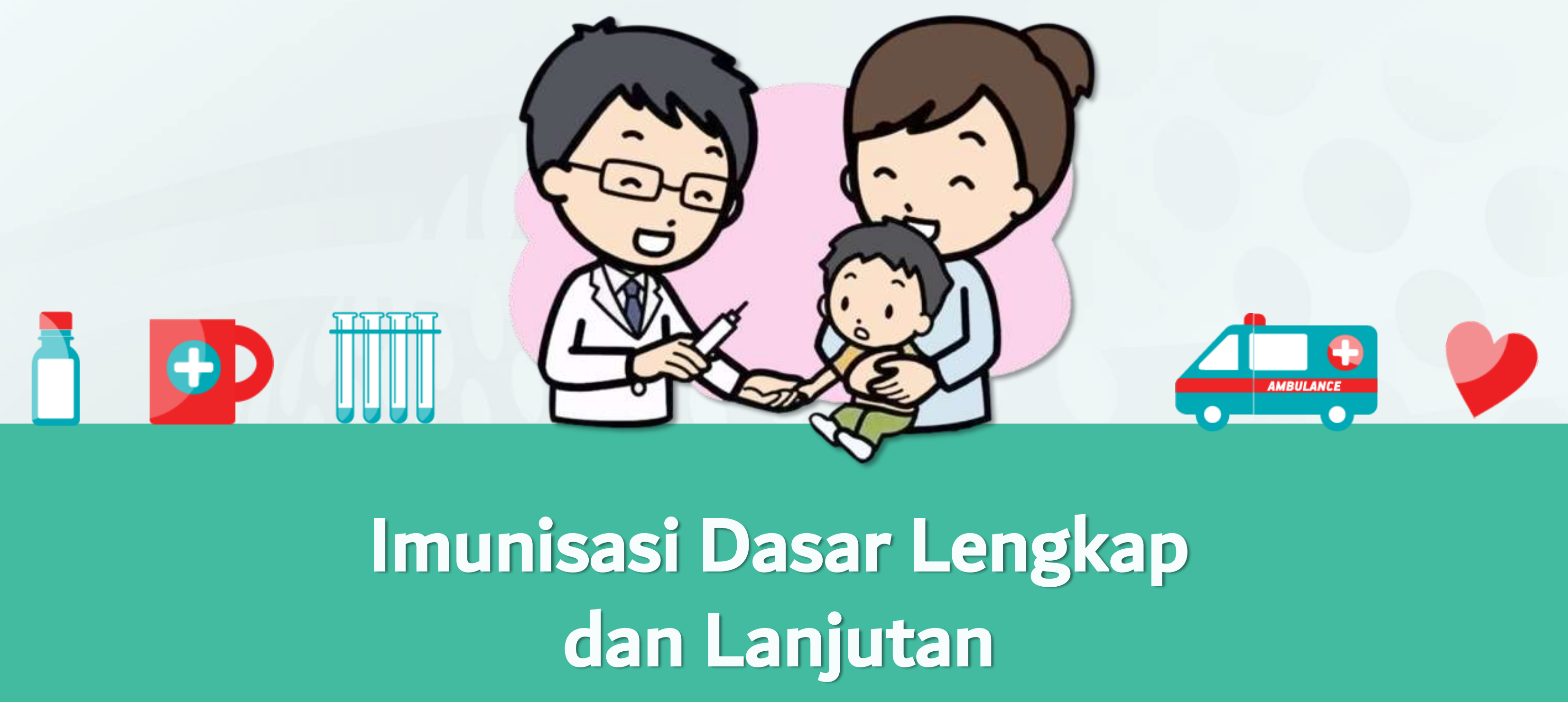


BCG

DPT-HB-HIB

3 HEP B

POLIO

5. CAMPAK 


\section{Jadwal Imunisasi Dasar}
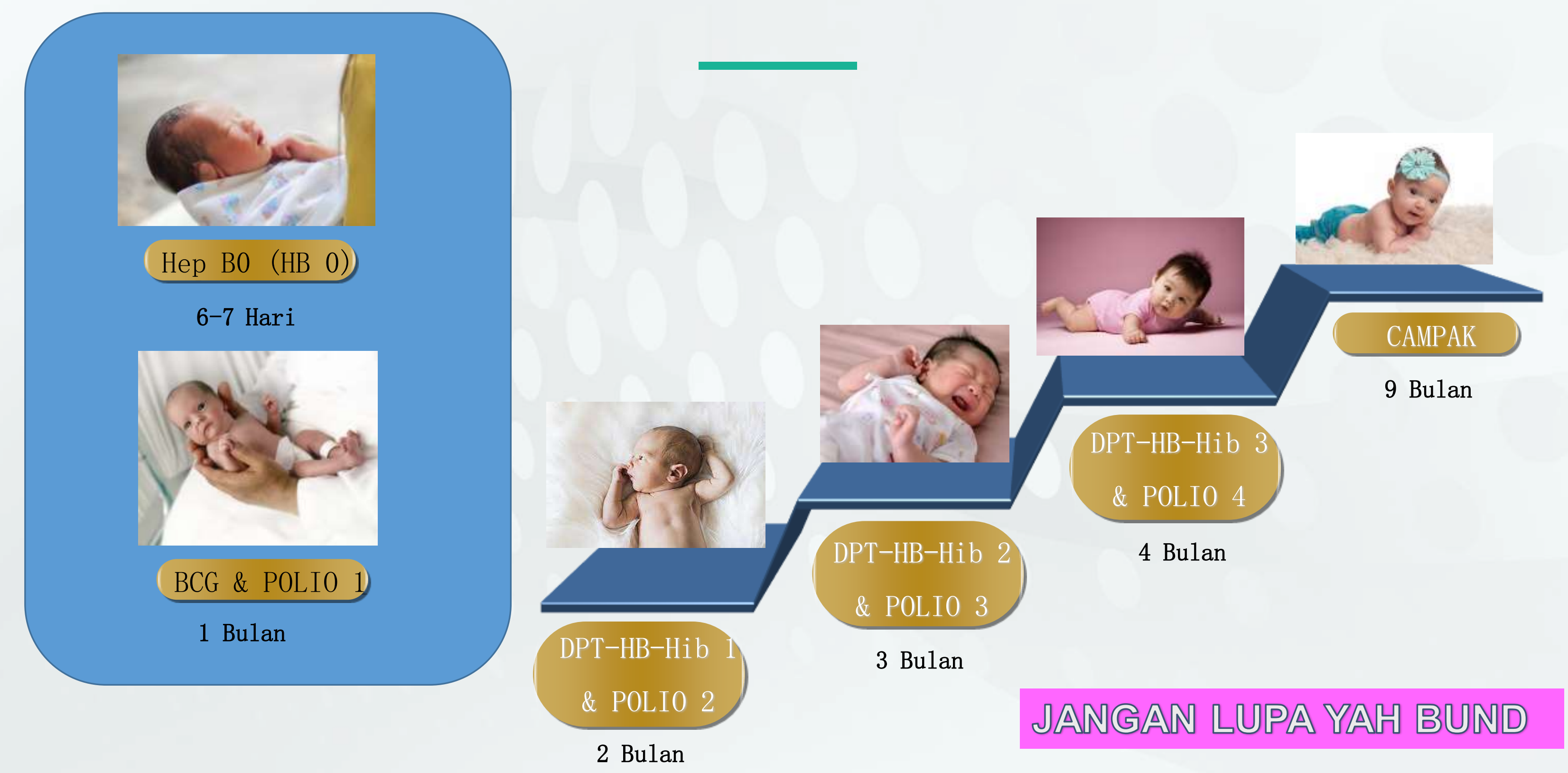


\section{Jadwal Imunisasi Dasar}

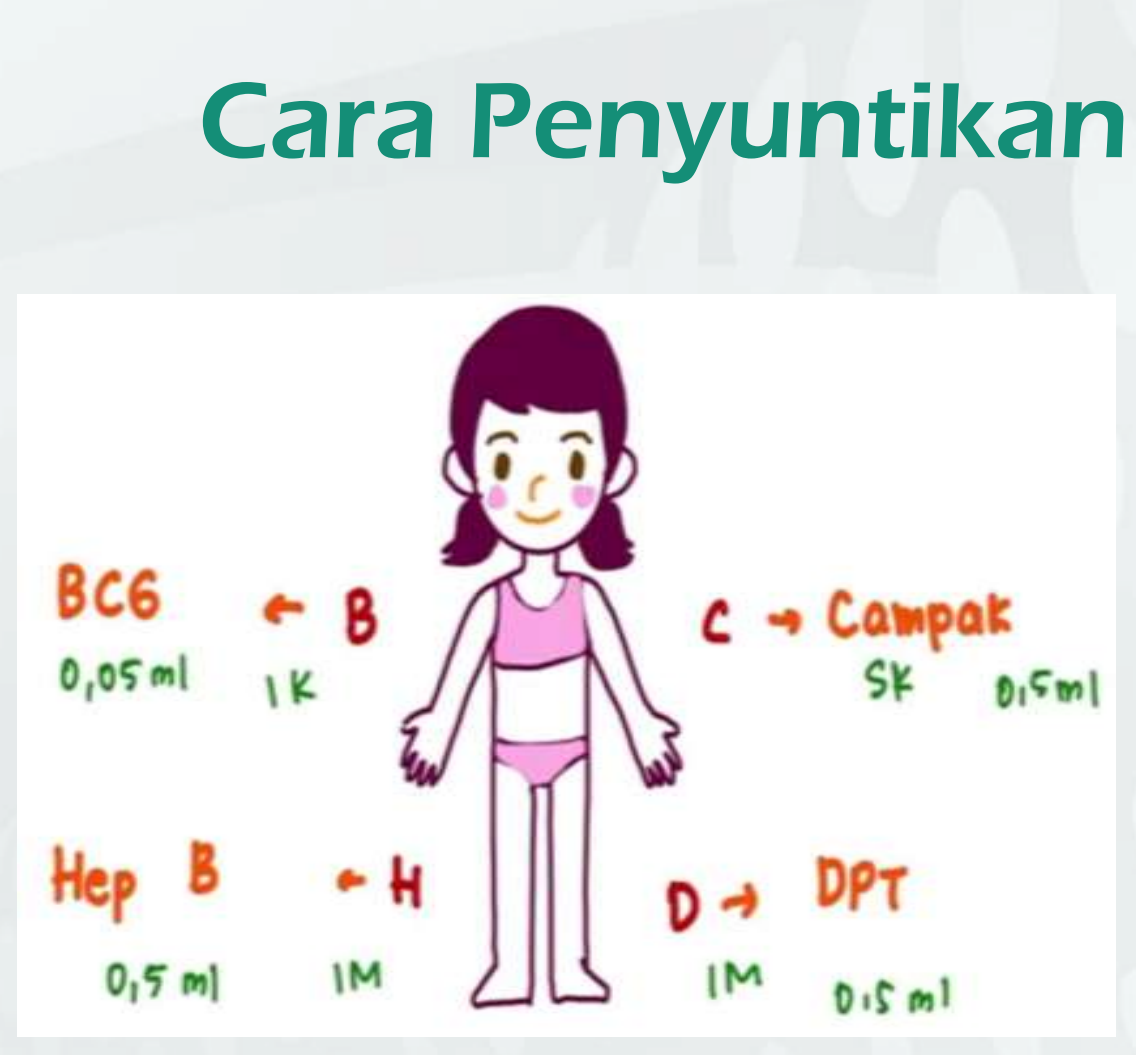

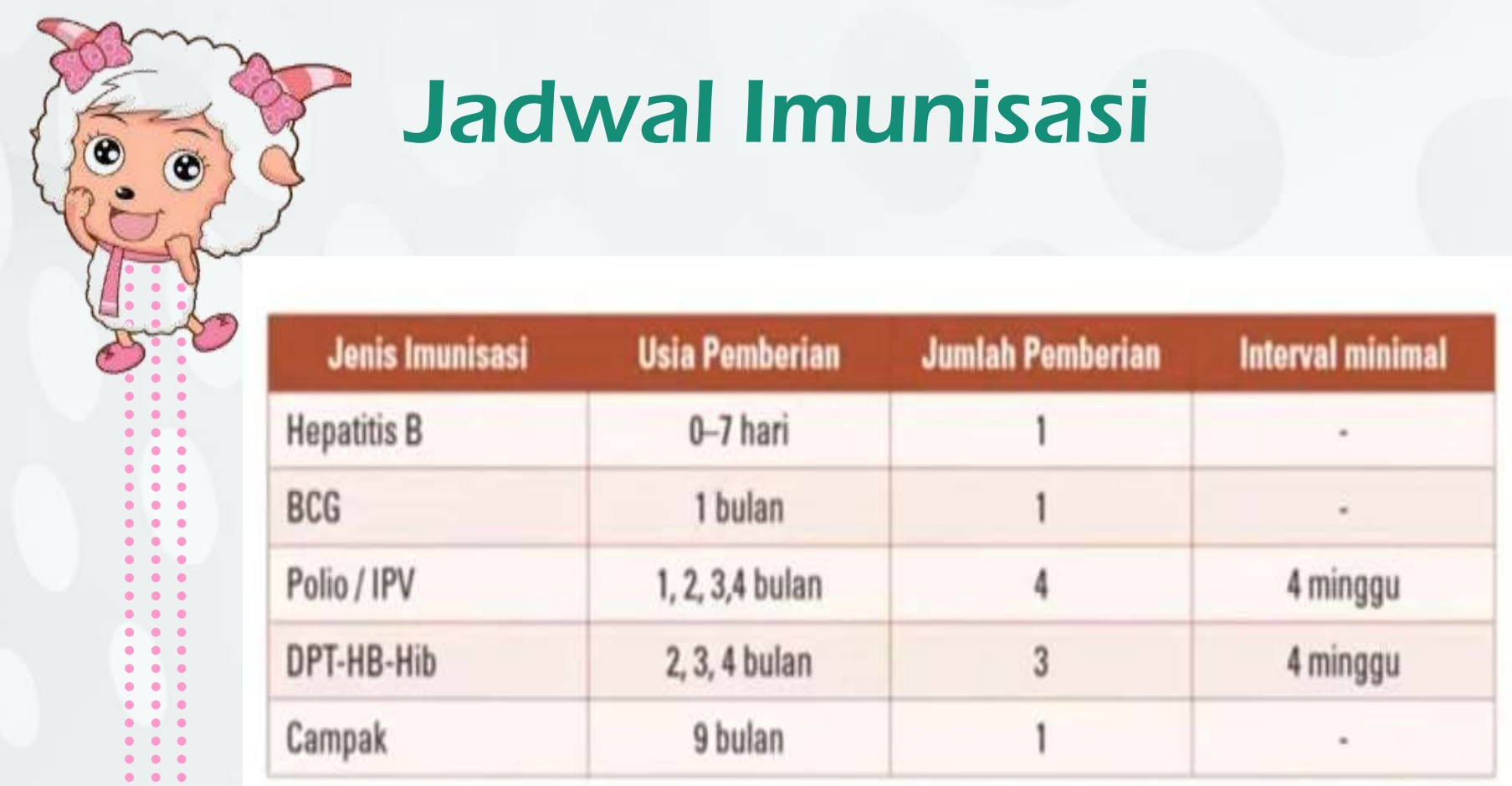




\section{Imunisasi Lanjutan}

BesaDVIA $=$

2) usis selohn =

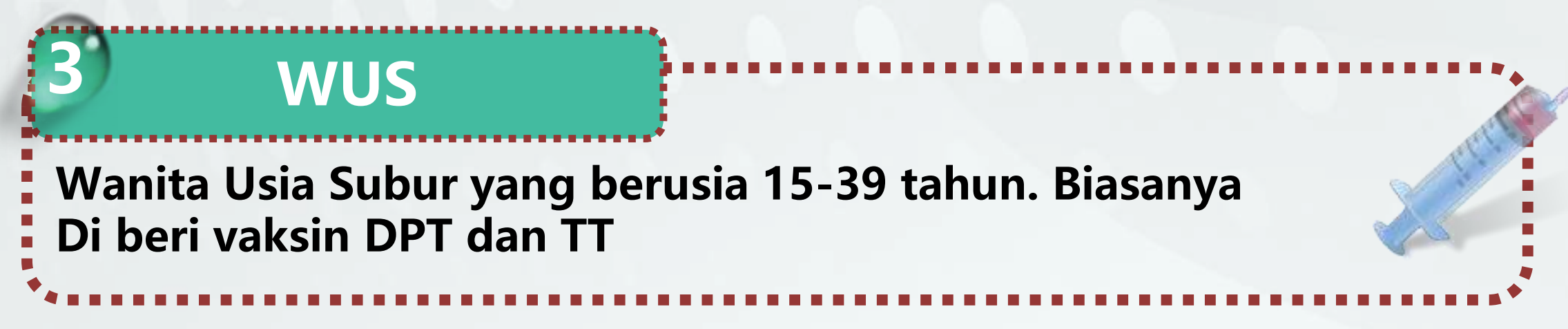




\section{Dampak Ketika tidak Imuniasi}

Penyakit TBC

Radang Selaput Otak

$\xi_{3}^{3}$ Terjangkit Hepatitis B

Kecacatan dan Kematian

$E^{n}=$ Polio

$\sum^{n} 3$ Ispa

注意事项

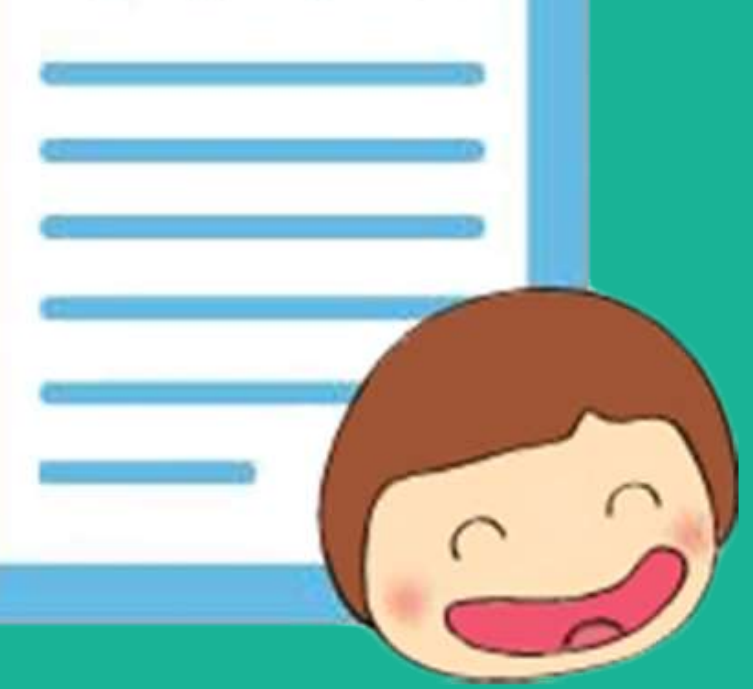




\section{DAFTAR PUSTAKA}

Sudarman, S., Aswadi, A., Syamsul, M., \& Gabut, M. Faktor Yang Berhubungan Dengan Kejadian Stunting Pada Balita di Wilayah Kerja Puskesmas Pannambungan Kota Makassar. Al GIZZAI: PUBLIC HEALTH NUTRITION JOURNAL, 1(1), 1-15.

Aritonang, J. (2018). Peningkatan Pengetahuan Ibu Tentang Imunisasi Pentabio Lanjutan Setelah Pemberian Pendidikan Kesehatan Di Puskesmas Lampaseh Aceh. Jurnal Riset Kesehatan Nasional, 2(2), 173-179.

Itsa, N. S., Perdani, R. R. W., \& Mutiara, H. (2020). Faktor-Faktor yang Berhubungan dengan Status Imunisasi Lanjutan Pentavalen (DPT-HB-Hib) di Wilayah Kerja Puskesmas Labuhan Ratu Kota Bandar Lampung Tahun 2018. Jurnal Majority, 9(1), 107-114.

Rizema P S. Asuhan Neonatus Bayi dan Balita untuk Keperawatan dan Kebidanan Jogjakarta: DMEDIKA; (2012).

Dampas, R. GambarPemberian Imunisasi Dasar Bayi Uisa 0-12 Bulan. Jurnal IlmiahBidan (Jidan), 2(2), 71-76, Juli 2014. 
Sudarman, S., Aswadi, A., Syamsul, M., \& Gabut, M. Faktor Yang Berhubungan Dengan Kejadian Stunting Pada Balita di Wilayah Kerja Puskesmas Pannambungan Kota Makassar. Al GIZZAI: PUBLIC HEALTH NUTRITION JOURNAL, 1(1),15.

Dirjen Pengendalian Penyakit dan Penyehatan Lingkungan, Kemenkes RI. 2013. Modul Pelatihan Imunisasi bagi petugas Puskesmas (Basic Health Worker's training module).

Dirjen Pengendalian Penyakit dan Penyehatan Lingkungan, Kemenkes RI. 2013. Petunjuk Teknis Introduksi Imunisasi DTP-HB-Hib (Pentavalen) Pada Bayi dan Pelaksanaan Imunisasi Lanjutan Pada Anak Balita

Rasuna Said. 2017. 5 dampak negative jika bayi tidak di imunisasi. Redaksi halodoc : Jakarta.

Syahrir, S., Ibrahim, I. A., Syarfaini, S., \& Kurniati, Y. Hubungan BBLR, Kebiasaan Merokok Keluarga, dan Status Gizi dengan Riwayat ISPA Bayi di Kelurahan Ballaparang. Al GIZZAI: PUBLIC HEALTH NUTRITION JOURNAL, 1(1), 27-35. 


\title{
QUOTES
}

“Penuhi Hak Anak untuk

\author{
Hidup Sehat
}

Melalui IMUNISASI"

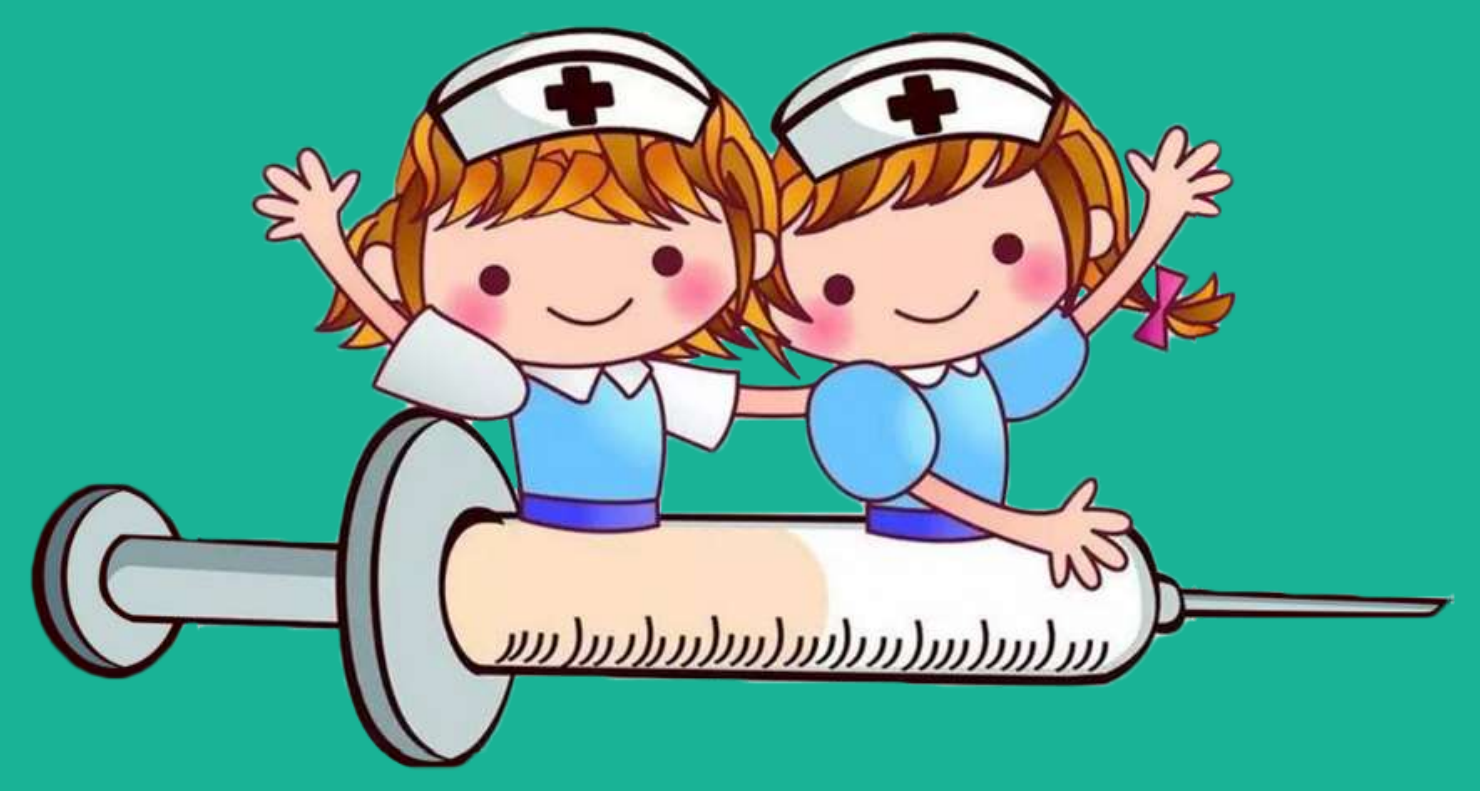

